\title{
DRYING KINETICS OF WEST INDIAN CHERRY: INFLUENCE OF OSMOTIC PRETREATMENT
}

\author{
MIRTES APARECIDA DA CONCEIÇÃO SILVA* \\ JEFFERSON LUIZ GOMES CORRÊA** \\ ZAQUEU ERNESTO DA SILVA***
}

\begin{abstract}
The purpose of this work was to study the influence of osmotic pretreatment on the convective drying kinetics of the West Indian cherry (Malpighia emarginata DC). Osmotic dehydration was performed with a $65^{\circ}$ Brix sucrose solution at room temperature, having the fruits immersed for 4 or 12 hours, using a 1:10 proportion of fruit:solution (w:w). After the osmotic dehydration, the fruits were convectively-dried at $50^{\circ} \mathrm{C}$ on a tray dryer. The convection drying was modeled based on Fick's second law, while the effective mass diffusion $\left(D_{e f}\right)$ was determined using Levenberg-Marquardt's minimization algorithm by means of the paradigm of inverse methods. The values of effective mass diffusion coefficients observed were in the same order of magnitude as those reported in the literature. The condition that promoted the highest value of diffusivity was convective drying preceded by 4 hours of osmotic dehydration. This condition was also the one with the best fit agreement of the tested model.
\end{abstract}

KEY-WORDS: CONVECTIVE DRYING; MASS TRANSFER; INVERSE METHOD; EFFECTIVE MASS DIFFUSION.

* Engenheira de Alimentos, Ph. D. em Engenharia Mecânica pelo Programa de Pós-Graduação em Engenharia Mecânica, Universidade Federal da Paraíba (PPGEM/UFPB), João Pessoa, PB (e-mail: mirtesacs@yahoo.com.br).

** Engenheiro Químico, Ph. D. em Engenharia Mecânica, Professor, Departamento de Ciência dos Alimentos, Universidade Federal de Lavras, Lavras, MG (e-mail: Jefferson@ufla.br).

*** Engenheiro Mecânico, Ph.D em Energia Térmica, Professor, Departamento de Pós-Graduação em Engenharia Mecânica, PPGEM/UFPB, João Pessoa, PB (e-mail: zaqueu@les.ufpb.br). 


\section{INTRODUCTION}

Drying is one of the oldest food preservation techniques currently used in several industrial processes (MUJUMDAR, 2006), and it is known for drastic alterations on the physical, nutritional and sensory properties of foods (RATTI, 2001). Osmotic dehydration has been indicated as an inexpensive and safe pretreatment for food-drying processes because it promotes fewer modifications of the final product with respect to the raw material than the conventional drying process (MASTRÀNGELO et al., 2000; SERENO, MOREIRA \& MARTINEZ., 2001; BRANDÃO et al., 2003; SOUSA et al., 2003; SOUZA NETO et al., 2005; SHIGEMATSU et al., 2005; REIS et al., 2007; DEROSSI et al., 2008).

Fruits constitute a common class of food suitable to be preserved by drying techniques. The main appeal of the West Indian cherry or acerola (Malpighia glabra L., Malpighia punicifolia L. or Malpighia emarginata DC.) is its high vitamin C content. This fruit is also rich in other nutrients such as carotenoids, thiamine, riboflavin and niacine (ASSIS, LIMA \& OLIVEIRA, 2001; ROSSO \& MERCADANTE, 2005; MARQUES, FERREIRA \& FREIRE, 2007). Drying processes have been studied by Jesus et al. (2003), Alves et al. (2004), Marques, Ferreira \& Freire (2007) and Corrêa et al. (2008), who evaluated the application of osmotic pretreatments and their effect on the quality of the final product, as well as the best operating conditions for osmotic dehydration.

The mass transfer rate during osmotic dehydration depends on the temperature and concentration of the solution, the nature and molecular mass of the dehydrating agent, the proportion of solution to food, the use of blanching, vacuum, overall geometry and cell structure the foodstuff (RASTOGI et al., 2002; TEDJO et al., 2002; SANTOS, 2003; ALVES et al., 2004; CHIRALT \& TALENS, 2005; MOURA; MASSON \& YAMAMOTO, 2005; MARTIM; WASZCZYNSKYJ \& MASSON, 2007; CORRÊA et al., 2008; CORRÊA et al., 2010, CORRÊA et al., 2011, FANTE et al., 2011).

Inverse problem analysis has innumerable relevant applications in engineering, medicine and other fields of science (BECK \& ARNOLD, 1977; LUGON JÚNIOR; SILVA NETO \& SANTANA, 2002, MEJIAS; ORLANDE \& OZISIK, 2003; KANEVCE; KANEVCE \& DULIKRAVICH, 2005; FGUIRI et al., 2007). Growing attention has been given to the analysis and solution of inverse problems of heat and mass transfer that use the inverse method to estimate thermophysical properties of foods (SILVA; SILVA \& MARIANI, 2009; SILVA; CORRÊA \& SILVA, 2010; SILVA et al., 2011).

In the present study the influence of osmotic dehydration and its pretreatment duration on the drying kinetics of acerola (West Indian cherry) was evaluated. The accuracy of an inverse method to estimate the effective mass diffusion of acerola subjected to convective drying was also tested.

\section{MATERIAL AND METHODS}

\subsection{MATERIAL}

Ripe, but firm acerola fruits were purchased from a local market in João Pessoa (PB) Brazil. The fruits were selected based on their appearance, skin color and absence of physical damage, as well as their average diameter. The dimensions of the acerola samples were measured with a Vernier caliper (SOMET) with a precision of $0.05 \mathrm{~mm}$ and the initial mass was measured using an analytical balance (MARTE) with a maximum capacity of $500 \mathrm{~g}$ and precision of $0.001 \mathrm{~g}$.

\subsection{PREPARATION OF THE SAMPLES}

The fresh acerolas were selected, washed and surface-dried with paper towels.

\subsection{PREPARATION OF THE SOLUTION}

The osmotic solution was prepared by adding granulated sucrose (Estrela brand) to water and mixing it until complete dissolution of the sucrose to a final concentration of $65^{\circ} \mathrm{Brix}$ (JESUS et al., 2003; JUSZCZAK; WITCZAK \& GALKOWSKA, 2009). 


\subsection{OSMOTIC DEHYDRATION}

The osmotic dehydration procedure was carried out in hermetically closed containers at room temperature (aprox. $27^{\circ} \mathrm{C}$ ) where fruits were immersed in the sucrose solution prepared at 65ํㅏix, obeying a proportion fruit:solution of 1:10 (w:w), for periods of 4 or $12 \mathrm{~h}$ (JESUS et al., 2003; ALVES et al., 2005; TELES et al., 2006; ANTONIO et al., 2008; DIONELLO et al., 2009).

\subsection{CONVECTIVE DRYING}

Drying experiments were performed by placing control (untreated) and osmotically pretreated acerola in aluminum crucibles which were than positioned in a convection tray dryer and the sample mass loss was monitored until constant weigh was achieved. In order to obtain drying kinetic curves samples were removed at intervals of $1 \mathrm{~h}$ (JESUS et al., 2003; SOUZA et al., 2003, DOYMAZ, 2008; DIONELLO et al., 2009)

\subsection{DETERMINATION OF THE MOISTURE CONTENT}

The moisture content was determined following the method described by Adolfo Lutz Institute (2005), addapted for use with acerola. This method consists of weighing one gram of crushed and homogenized sample and placing it in an oven (LUFERCO, model 41181) to dry at $65^{\circ} \mathrm{C}$ for $24 \mathrm{~h}$, until its weight remains constant.

\subsection{DETERMINATION OF THE EFFECTIVE MASS DIFFUSION}

Water mass transfer controlled by diffusion during decreasing drying rates can be described by Fick's second law. Several authors have used this diffusion theory (LIMA QUEIROZ \& NEBRA, 2002; BABALIS et al., 2006; NGUYEN \& PRICE, 2007; PRACHAYAWARAKORN et al., 2008; DOYMAZ, 2008) with good agreement to their experimental data.

Effective mass diffusivity was calculated based on the paradigm referred to as the inverse method, using the Levenberg-Marquardt minimization algorithm to solve Fick's equation in spherical coordinates (Eq. 1). A computer program in Fortran 90 language was used, having as input data an initial diffusivity value found in the reviewed literature, the values of initial and equilibrium moisture content the data of the evolution of transient moisture, which were determined experimentally.

$$
\frac{1}{r^{2}} \frac{\partial}{\partial r}\left(D_{e f} r^{2} \frac{\partial X}{\partial r}\right)=\frac{\partial X}{\partial t}
$$

The Levenberg-Marquardt method is very stable, robust and straightforward, and has been applied to a wide range of inverse problems due to its good convergence rate (KANEVCE, KANEVCE \& DULIKRAVICH, 2005; MENDONÇA; CELSO FILHO \& SILVA, 2005; FGUIRI et al., 2007; MONTEAU 2008).

For the inverse problem of interest here, the effective mass diffusion, $D_{\text {ef }}$, is considered an unknown parameter while all the other parameters used for the solution of the direct problem are known. To determine the effective mass diffusion it was assumed that $D_{\text {ef }}$ remains constant at a given temperature and experimental data of the evolution of transient moisture content $\left(Y_{j}\right)$ was gathered when acerola was subjected to a drying process with or without the osmotic dehydration pretreatment.

\subsection{DRYING KINETICS MODEL}

The evolution of transient moisture was determined through a direct problem that was solved 
analytically, considering acerola's simple spherical geometry and assuming that the thermophysical properties were constant (DOYMAZ, 2008).

The analytical solution of Equation (1) by the method of separation of variables was obtained by applying the initial and boundary conditions (Eqs. 2-4):

Initial condition:

$$
X=X_{0} \quad t=0, \quad 0<r<R
$$

Boundary conditions:

$$
\begin{array}{ccc}
\frac{\partial X}{\partial r}=0 & t>0, & r=0 \\
X=X_{e q} & t>0, & r=R
\end{array}
$$

The solution to Eq. (1) is given by the following equation:

$$
Y=\frac{\bar{X}-X_{e q}}{X_{0}-X_{e q}}=\frac{6}{\pi^{2}} \sum_{n=1}^{\infty} \exp \left(-n^{2} \cdot \pi^{2} \cdot D_{e f} \cdot \frac{t}{r_{1}^{2}}\right)
$$

The representative curves of the modeling of moisture evolution were obtained with a computer program in Fortran 90 language, using as input parameters the effective mass diffusion calculated by the inverse problem, the number of points and the data on the temporal evolution of moisture obtained experimentally, the initial and equilibrium moisture contents, and the total time of the experiment.

\section{RESULTS AND DISCUSSION}

\subsection{DRYING KINETICS}

Figure 1 presents the curves of the acerola drying kinetics with and without pretreatment by osmotic dehydration.

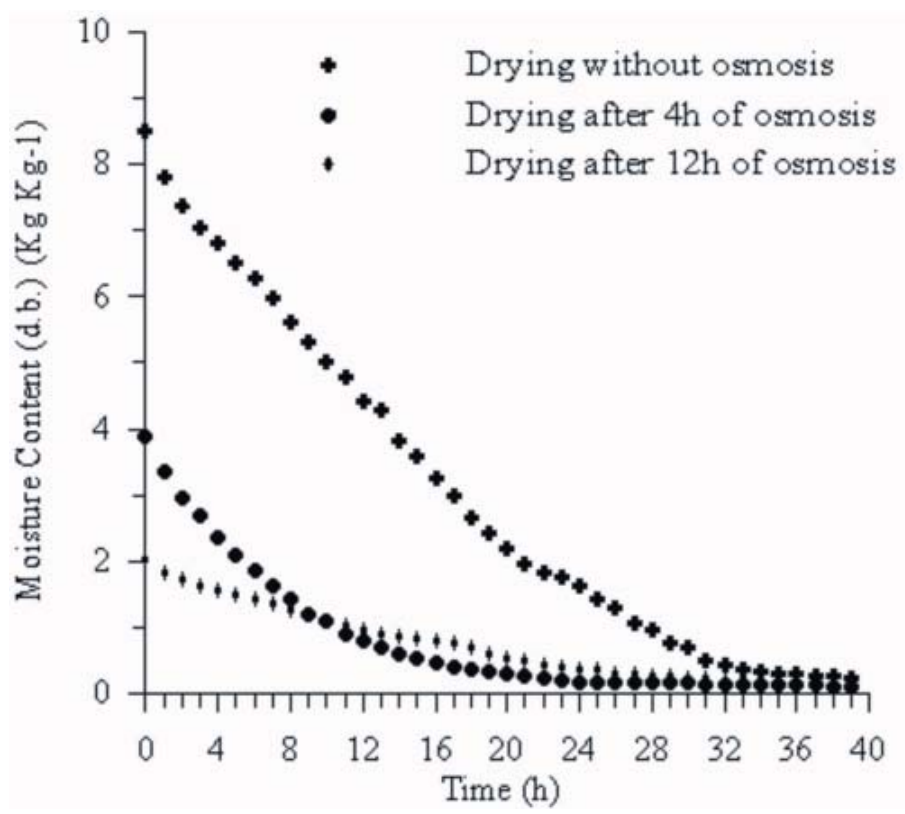

FIGURE 1 - ACEROLA DRYING KINETICS WITH AND WITHOUT OSMOTIC PRETREATMENT 
A comparison of the initial moisture content (Figure 1) indicates that increasing the duration of the osmotic dehydration led to lower values of moisture content, resulting in lower initial moisture content in the drying process. This demonstrates the efficiency of osmotic dehydration in reducing the moisture content. Moreover, with osmotic treatment of both 4 and 12 hours, the moisture content of the acerola samples was close to equilibrium after approximately 24 hours of drying, while without osmotic dehydration, approximation to equilibrium conditions was reached after 32 hours of processing. Although the $12 \mathrm{~h}$ treatment led to lower moisture content at the beginning of drying, after $8 \mathrm{~h}$ within drying the values of moisture were very similar for the two pretreatment cases when comparing the curves of the kinetics of fruit treated osmotically for 4 and 12 hours.

Figures 2 to 4 ilustrate the moisture distribution and the residual values found by comparing the experimental measurements and those calculated by the proposed model, respectively. The residues were obtained from the difference between the experimental values and the values of the model obtained by using the estimated parameter. For the analysis in question, the variation of the residues for the three cases under study was calculated, resulting in the following values: -2.0415 to 1.451 for the drying of fresh fruit, -0.4085 to 0.24159 for drying after $4 \mathrm{~h}$ of osmosis, and -0.248 to 0.258 for during after $12 \mathrm{~h}$ of osmosis.

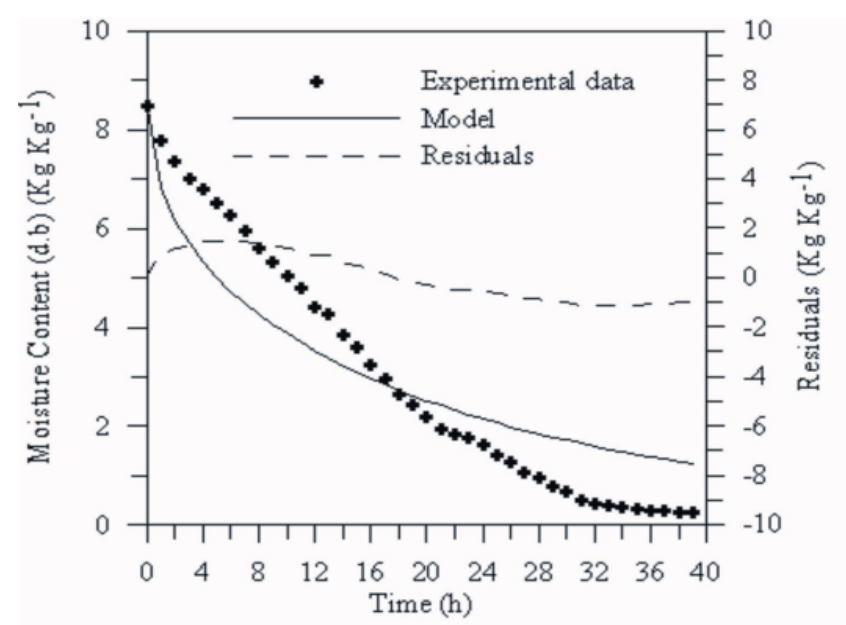

FIGURE 2 - RESIDUES OBTAINED FOR DRYING OF FRESH ACEROLA

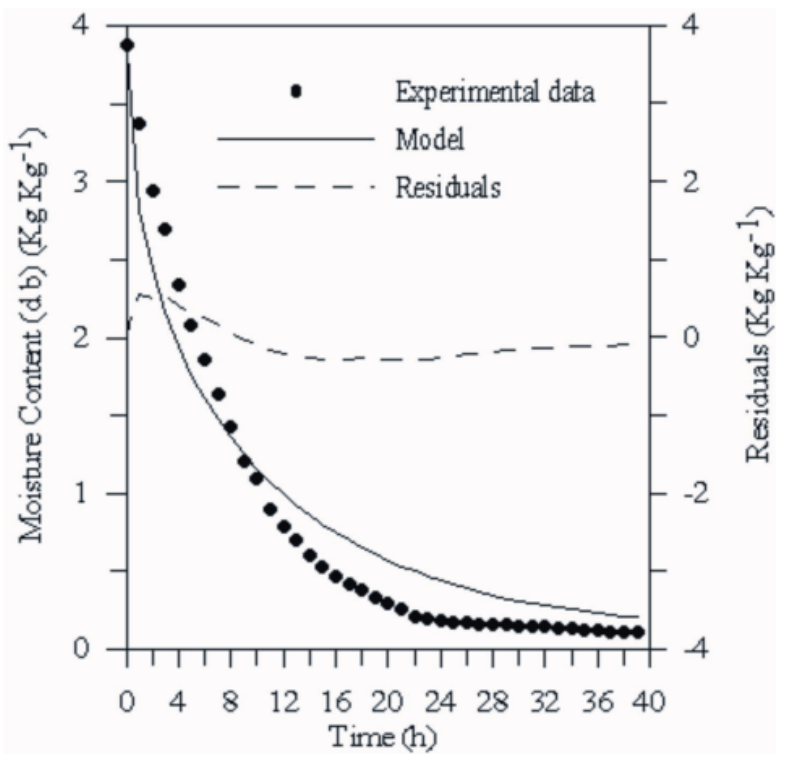

FIGURE 3 - RESIDUES OBTAINED FOR DRYING OF ACEROLA AFTER $4 \mathrm{~h}$ OF OSMOSIS 
A comparison of the curves adjusted to the model and the experimental curves, in the three cases, indicated that the best fit was obtained for the samples subjected to 4 hours of osmotic pretreatment. The untreated fresh fruit and the fruit pretreated osmotically for 12 hours showed layers of wax and sucrose, respectively, on the surface of the fruit. Because the descriptive model used does not consider such resistances to mass transfer, the adjustments were only satisfactory, whereas the better adjustment obtained in the case of 4 hours osmotic pretreatment is likely due to the absence of these layers and the rupture of the layer of wax of the fresh product induced by such preatreatment.

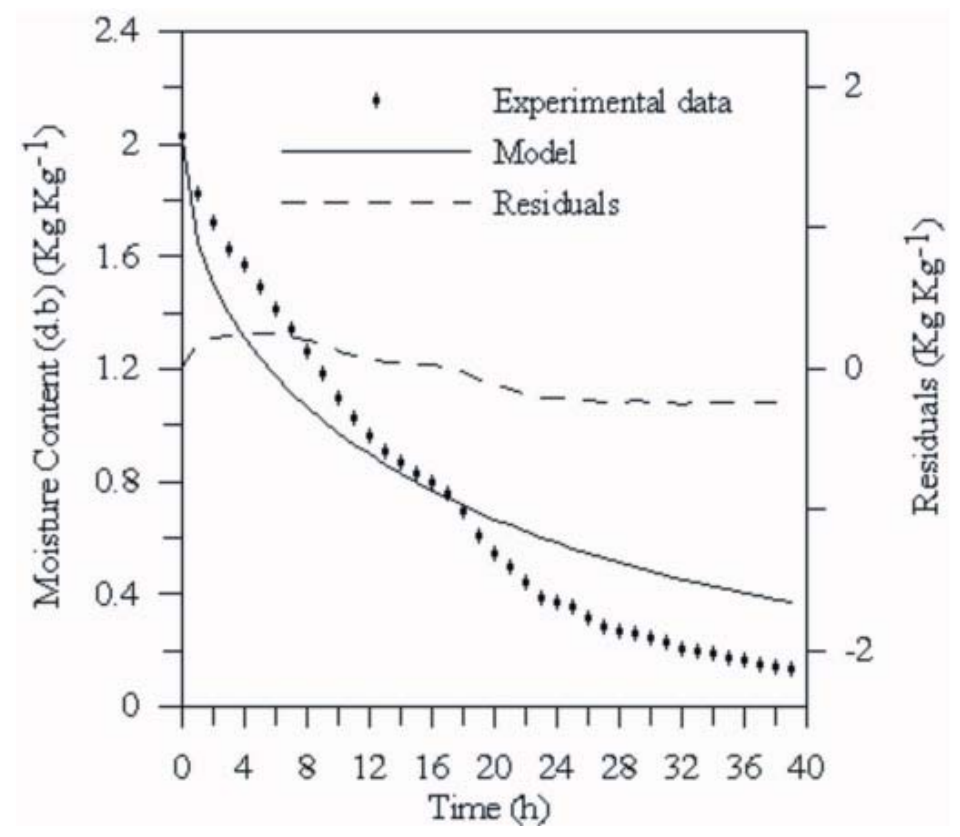

\section{FIGURE 4 - RESIDUES OBTAINED FOR DRYING OF ACEROLA AFTER 12 h OF OSMOSIS}

\subsection{EFFECTIVE MASS DIFFUSION}

Table 1 presents the values of the effective mass diffusion estimated by the LevenbergMarquardt minimization algorithm. The highest values of effective diffusion were obtained for the samples pretreated osmotically for 4 hours. This finding is consistent with the work of Park; Bin \& Brod (2002) and Alves et al. (2004), who also found an increase in effective diffusion when drying sliced pears and acerolas, respectively, indicating an increase in the mass transfer rate in drying processes preceded by osmotic dehydration.

On the other hand, the samples subjected to osmotic dehydration for a period of 12 hours presented effective diffusion values similar to those obtained in drying processes without osmotic pretreatment. It is believed that the longer immersion time led to the formation of a surface barrier of incorporated solids that hindered the removal of water in the osmotic dehydration and drying processes. Sucrose may act as an additional resistance to the transfer of water between fruit and solution, possibly due to the size of sucrose molecules (TELES et al., 2006). This hypothesis corroborates the findings of Nieto, Castro and Alzamora (2001), who reported that the increase in the impregnation of the solute in the product's surface layer causes a reduction of the effective diffusion.

The inverse method employed here allowed for the determination of the effective mass diffusion as a function of the moisture content, and showed good agreement with to the values found in the literature. 


\section{TABLE 1 - ESTIMATE OF EFFECTIVE DIFFUSION DURING THE DRYING OF ACEROLA}

\begin{tabular}{lll}
\hline & Effective diffusion $\left(\mathrm{m}^{2} \mathrm{~s}^{-1}\right)$ & Uncertaintly \\
\hline Drying without osmosis & $7.865 \times 10^{-11}$ & $6.844 \times 10^{-15}$ \\
Drying after 4 h of osmosis & $16.21 \times 10^{-11}$ & $3.662 \times 10^{-14}$ \\
Drying after 12 h of osmosis & $7.723 \times 10^{-11}$ & $2.812 \times 10^{-14}$ \\
\hline
\end{tabular}

\section{CONCLUSION}

In the experiments with osmotic dehydration, the reduction of the moisture content of the fruits was proportional to the duration of immersion in solution.

The inverse method applied to the estimation of effective mass diffusion proved very stable and robust, since the uncertainties were 3 decimal places lower than that of the estimated parameter. Additionally, it showed good agreement with the values reported in the literature. Further adjustments should include the shrinkage factor.

Within the operational conditions tested for osmotic dehydration of acerola as a pretreatment of its convective drying process, the immersion for $4 \mathrm{~h}$ resulted in the best agreement of the model and highest values of effective mass diffusion. Even though an osmotic pretreatment led to lower moisture content in the subsequent drying process, the moisture content in both situations was the same after 8 hours of convective drying. Moreover, the $4 \mathrm{~h}$ pretreatment resulted in the best agreement of the model with the experimental findings and the highest values of effective mass diffusion.

\section{RESUMO \\ CINÉTICA DE SECAGEM DE ACEROLA: INFLUÊNCIA DO TRATAMENTO OSMÓTICO}

O objetivo deste trabalho foi estudar a influência do pré-tratamento osmótico na cinética de secagem convectiva de acerolas (Malpighia emarginata D.C.). A desidratação osmótica foi realizada com solução de sacarose a 65ㅂix à temperatura ambiente com 4 e 12 horas de imersão na proporção fruta:solução de 1:10 (p:p). Após a desidratação osmótica, procedeu-se à secagem convectiva da acerola em secador de bandejas a $50^{\circ} \mathrm{C}$. A modelagem da secagem convectiva foi realizada com base na segunda Lei de Fick e a determinação da difusividade mássica efetiva $\left(D_{\mathrm{ef}}\right)$ com base no algoritmo de minimização de Levenberg-Marquardt, usando-se o paradigma dos métodos inversos. Os valores de difusidade mássica efetiva obtidos foram da mesma ordem de grandeza dos encontrados na literatura. A condição mais conveniente testada foi a secagem convectiva precedida de 4 horas de desidratação osmótica, uma vez que apresentou melhor ajuste com o modelo proposto e também conduziu aos maiores valores de difusividade mássica efetiva.

PALAVRAS-CHAVE: SECAGEM CONVECTIVA; TRANSFERÊNCIA DE MASSA; MÉTODO INVERSO; DIFUSIVIDADE MÁSSICA EFETIVA.

\section{REFERENCES}

1 ALVES, D. G.; ANTONIO, G. C.; JÚNIOR, J. L. B.; MURR, F. E. X. Drying kinetics of osmotically dehydrated West Indian cherry fruit (Malpighia punicifolia L.). In: INTERNATIONAL DRYING SYMPOSIUM, 14 ${ }^{\text {th }}$, São Paulo, 2004. Proccedings ... São Paulo: UNICAMP, 2004. CD-ROM.

2 ALVES, D. G.; JÚNIOR, J. L. B.; ANTONIO, G. C.; MURR, F. E. X. Osmotic dehydration of acerola fruit (Malpighia punicifolia L.). Journal of Food Engineering, v.68, p. 99-103, 2005.

3 ANTONIO, G. C.; AZOUBEL, P. M.; MURR, F. E. X.; PARK, K.J. Osmotic dehydration of sweet potato (Ipomoea batatas) in ternary solutions. Ciência e Tecnologia de Alimentos, v.28, n.3, p.696-701, 2008. 
4 ASSIS, S. A.; LIMA, D. C.; OLIVEIRA, O. M. M. F. Activity of pectin methylesterase, pectin content and vitamin C in acerola fruit at various stages of fruit development. Food Chemistry, v.74, n.2, p.133-137, 2001.

5 BABALIS, S.J.; PAPANICOLAOU, E.; KYRIAKIS, N.; BELSSIOTIS, V.G. Evaluation of thin-layer drying models for describing drying kinetics of figs (Ficus carica). Journal of Food Engineering, v.75, n.2, p.205-214, 2006.

6 BECK, J. V.; ARNOUD, K.J. Parameter estimation in engineering and science. New York: John Wiley \& Sons, 1977.

7 BRANDÃO, M.C.C.; MAIA, G.A.; LIMA, D.P.; PARENTE, E.J.S.; CAMPELLO, C.C.; NASSU, R.T.; FEITOSA, T.; SOUSA, P.H.M. Análise físico-química, microbiológica e sensorial de frutos de manga submetidas à desidratação osmótico-solar. Revista Brasileira de Fruticultura, v.25, n.1, p.38-41, 2003.

8 CHIRALT, A.; TALENS, P. Physical and chemical changes induced by osmotic dehydration in plant tissues. Journal of Food Engineering, v.67, n.1-2, p. 167-177, 2005.

9 CORRÊA, J. L. G.; CACCIATORE, F. A.; SILVA, Z. E.; ARAKAKI, T. Desidratação osmótica de acerola (Malpighia emarginata D.C) - cinética de transferência de massa. Revista Ciência Agronômica, v.39, n.3, p.403-409, 2008.

10 CORRÊA, J. L. G.; PEREIRA, L. M.; VIEIRA, G. S.; HUBINGER, M. D. Mass transfer kinetics of pulsed vacuum osmotic dehydration of guavas. J. Food Engineering, v.96, p.498-504, 2010.

11 CORRÊA, J. L. G.; DEV, S. R. S.; GARIEPY, Y.; RAGHAVAN, G. S. V. Drying of pineapple by microwave-vacuum with osmotic pretreatment. Drying Technology, v.29, p.1556-1561, 2011.

12 DEROSSI, A.; DE PILLI, T.; SEVERINI, C.; McCARTHY, M.J. Mass transfer during osmotic dehydration of apples. Journal of Food Engineering, v.86, n.4, p.519-528, 2008.

13 DiOnEllo, R. G.; BeRBERT, P. A.; MOlinA, M. A. B.; PEREIRA, R. C.; VIANA, A. P.; CARLESSO, V.O. Secagem de fatias de abacaxi in natura e pré-desidratada por imersão-impregnação: cinética e avaliação de modelos. Ciência e Tecnologia de Alimentos, v.29, n. 1, p.232-240, 2009.

14 DOYMAZ, I. Convective drying kinetics of strawberry. Chemical Engineering and Processing, v.47, n.5, p.914-919, 2008

15 FANTE, C.; CORREAA, J.; NATIVIDADE, M.; LIMA, J.; LIMA, L. Drying of plums (Prunus SP, c.v Gulfblaze) treated with $\mathrm{KCl}$ in the field and subjected to pulsed vacuum osmotic dehydration. International Journal of Food Science and Technology, v.46, p.1080-1085, 2011.

16 FGUIRI, A.; DAOUAS, N.; BORJINI, N.; RADHOUANI, M.-S.; AÏSSIA, H.B. Experimental inverse analysis for the determination of boundary conditions in the parallel hot wire technique. Experimental Thermal and Fluids Science, v.31, n.3, p.209-220, 2007

18 INSTITUTO ADOLFO LUTZ. Métodos físico-químicos para análise de alimentos. 4 ed. Brasília: Ministério da Saúde, Agência Nacional de Vigilância Sanitária, 2005. 1018 p. (série A, Normas e Manuais Técnicos).

19 JESUS, M.F.; SCARANTO, V.L; JALALI, V.R.R; SILVA, G.F. Produção de passas de acerola em secador de bandeja. Revista Brasileira de Produtos Agroindustriais, v. 5, n.1, p.81-87, 2003.

20 JUSZCZAK, L.; WITCZAK, M.; GALKOWSKA, D. Flow behaviour of black chokeberry (Aronia melanocarpa) juice. International Journal of Food Engineering, v.5, p. 1-9, 2009.

21 KANEVCE, L.; KANEVCE, G.; DULIKRAVICH, G. Application of inverse concepts to drying. Thermal Science, v. 9, n. 2, p.31-44, 2005.

22 LIMA, A.G.B.; QUEIROZ, M.R.; NEBRA, S.A. Simultaneous moisture transport and shrinkage during drying of solids with ellipsoidal configuration. Chemical Engineering Journal, v.86, n.1-2, p.85-93, 2002.

23 LUGON JÚNIOR, J.; SILVA NETO, A.J.; SANTANA, C.C. Estimativa de isotermas de adsorção gás-liquido usando a abordagem de problema inverso. Tendências em Matemática Aplicada e Computacional, v.3, n.2, p.161-170, 2002

24 MARQUES, L. G.; FERREIRA, M. C.; FREIRE, J. T. Freeze-drying of acerola (Malpighia glabra L.). Chemical Engineering and Processing, v.46, n.5, p.451-457, 2007.

25 MARTIM, N. S. P. P.; WASZCZYNSKYJ, N.; MASSON, M. L. Cálculo das variáveis na desidratação osmótica de manga cv. Tommy Atkins. Ciência e Agrotecnologia, v.31, n.6, p.1755-1759, 2007.

26 MASTRÁNGELO, M.M.; ROJAS, A.M.; CASTRO, M.A.; GERSCHENSON, L.N.; ALZAMORA, S.M. Texture and structure of glucose-infused melon. Journal of the Science of Food and Agriculture, v.80, n. 6, p.769-776, 2000. 
27 MEJIAS, M. M.; ORLANDE, H. R. B.; ÖZISIK, M. N. Effect of the heating process and body dimensions on the estimation of the thermal conductivity components of orthotropic solids. Inverse Problems in Engineering, v. 2, n. 1, p. 75-89, 2003.

28 MENDONÇA, S.L.R.; CELSO FILHO, R.B.; SILVA, Z.E. da. Transient conduction in spherical fruits: method to estimate the thermal conductivity and volumetric thermal capacity. Journal of Food Engineering, v.67, n.3, p.361-366, 2005.

29 MONTEAU, J-Y. Estimation of thermal conductivity of sandwich bread using an inverse method. Journal of Food Engineering, v.85, n.1, p.132-140, 2008.

30 MOURA, C. P.; MASSON, M. L.; YAMAMOTO, C. I. Effect of osmotic dehydration in the apple (Pyrus malus) varieties Gala, Gold and Fugi. Thermal Engineering, v.4, n.1, p.46-49, 2005.

31 MUJUMDAR, A.S. Handbook of industrial drying. $3^{\text {rd }}$ edition, New York: Taylor and Francis Group, 2006.

32 NGUYEN, M-H.; PRICE, W.E. Air-drying of banana: influence of experimental parameters, slab thickness, banana maturity and harvesting season. Journal of Food Engineering, v.79, n.1, p.200-207, 2007.

33 NIETO, A.; CASTRO, M.A.; ALZAMORA, S.M. Kinetics of moisture transfer during air drying of blanched and/or osmotically dehydrated mango. Journal of Food Engineering, v.50, n.3, p.175-185, 2001.

34 PARK, K.J.; BIN, A.; BROD, F.P.R. Drying of pear d'Anjou with and without osmotic dehydration. Journal of Food Engineering, v.56, n.1, p. 97-103, 2002.

35 PRACHAYAWARAKORN, S.; TIA, W.; PLYTO, N.; SOPONRONNARIT, S. Drying kinetics and quality attributes of low-fat banana slices dried at high temperature. Journal of Food Engineering, v.85, n.4, p.509-517, 2008.

36 RASTOGI, N.K.; RAGHAVARAO, K.S.M.S.; NIRANJAN, K.; KNORR, D. Recent developments in osmotic dehydration: methods to enlace mass transfer. Trends in Food Science \& Technology, v.13, n.2, p.48-59, 2002.

37 RATTI, C. Hot air and freeze-drying of high-value foods: review. Journal of Food Engineering, v.49, n.2, p.311-319, 2001.

38 REIS, K.C.; AZEVEDO, L.F.; SIQUEIRA, H.H.; FERRUA, F.Q. Avaliação físico-química de goiabas desidratadas osmoticamente em diferentes soluções. Ciência e Agrotecnologia, v.31, n.3, p.781-785, 2007.

39 ROSSO, V.V.; MERCADANTE, A.Z. Carotenoid composition of two Brazilian genotypes of acerola (Malpighia punicifolia L.) from two harvests. Food Research International, v.38, n. 8-9, p.1073-1077, 2005.

40 SANTOS, C.N.P. Elaboração de um estruturado de polpa de manga (Mangifera indica L. cv Tommy atkins) parcialmente desidratado por osmose. 2003. 77 f. Dissertação (Tecnologia de Alimentos), Universidade Estadual de Campinas, Campinas, 2003.

41 SERENO, A.M.; MOREIRA, R.; MARTINEZ, E. Mass transfer coefficients during osmotic dehydration of apple in single and combined aqueous solutions of sugar and salt. Journal of Food Engineering, v.47, n.1, p.43-49, 2001.

42 SHIGEMATSU, E.; EIX, N.M.; XIMURA, M.; MAURO, M.A. Influência de pré-tratamentos sobre a desidratação osmótica de carambolas. Ciência e Tecnologia de Alimentos, v.25, n.3, p.536-545, 2005.

43 SILVA, C. K. F.; SILVA, Z. E., MARIANI, V. C. Determination of the diffusion coefficient of dry mushrooms using the inverse method. Journal of Food Engineering, v. 95, p. 1-10, 2009.

44 SILVA, M. A. C.; CORRÊA, J. L. G.; SILVA, Z. E. Application of inverse methods in the osmotic dehydration of acerola. International Journal of Food Science and Technology, v.45, p.2477-2484, 2010.

45 SILVA, M. A. C.; SILVA, Z. E.; MARIANI, V. C.; DARCHE, S. Mass transfer during the osmotic dehydration of west Indian cherry. LWT - Food Science and Technology, doi:10.1016/j.Iwt.2011.07.032, 2011.

46 SOUSA, P. H. M.; MAIA, G. A.; SOUZA FILHO, M. S. M.; FIGUEIREDO, R. W.; SOUZA A. C. R. Goiabas desidratadas osmoticamente seguida de secagem em estufa. Revista Brasileira de Fruticultura, v.25, n.3, p.414-416, 2003.

47 SOUZA NETO, M.A.; MAIA, G. A.; LIMA, J. R.; FIGUEIREDO, R. W.; SOUZA FILHO, M. S. M.; LIMA, A. S. Desidratação osmótica de manga seguida de secagem convencional: avaliação das variáveis de processo. Ciência e Agrotecnologia, v.29, n.5, p.1021-1028, 2005.

48 TEDJO, W.; TAIWO, K.A.; ESHTIAGHI, M.N; KNORR, D. Comparison of pretreatment methods on water and solid diffusion kinetics of osmotically dehydrated mangos. Journal of Food Engineering, v.53, n.2, p. 133-142, 2002. 
49 TELES, U. M.; FERNANDES, F.A.N.; RODRIGUES, S.; LIMA, A.S.; MAIA, G.A.; FIGUEIREDO, R.W. Optimization of osmotic dehydration of melons followed by air-drying. International Journal of Food Science and Technology, v.41, n.6, p.674-680, 2006.

\section{ACKNOWLEDGMENTS}

The authors gratefully acknowledge the financial support of the Brazilian research funding agency CNPQ (National Council for Scientific and Technological Development) - Process: 141522/2007-0. 